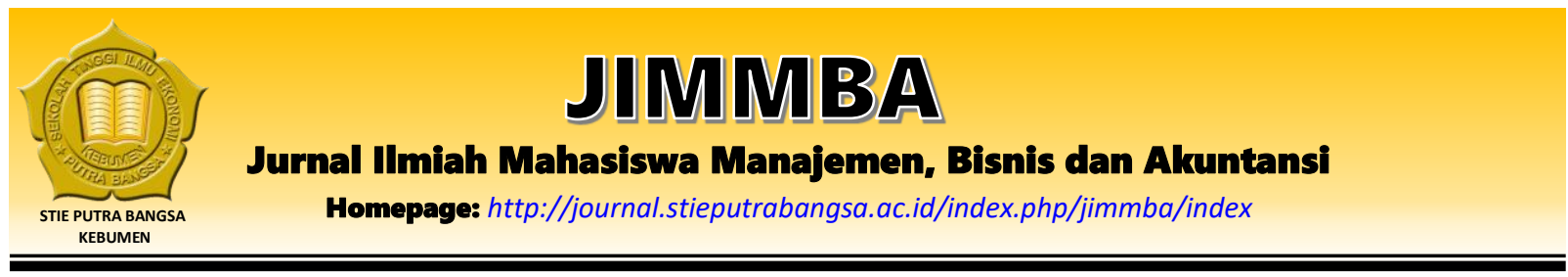

\title{
Pengaruh Likuiditas, Leverage, Intensitas Persediaan Terhadap Tingkat Agresivitas Pajak Pada Perusahaan Manufaktur sub sektor Logam dan Sejenisnya yang Terdaftar di BEI Tahun 2018-2019
}

\author{
Mona Monica Hutagalung, ${ }^{1}$ Martinus Ismail ${ }^{2}$ \\ 1,2Universitas Advent Indonesia \\ Email: hutagalungmonamonica@gmail.com¹, marthin_smile@unai.edu²
}

\begin{tabular}{|c|c|}
\hline ARTICLE INFO & ABSTRACT \\
\hline $\begin{array}{l}\text { Article History: } \\
\text { Received: December } 6^{\text {th }} 2020 \\
\text { Accepted: December } 23^{\text {th }} 2020 \\
\text { Published: December } 31^{\text {st }} 2020\end{array}$ & $\begin{array}{l}\text { Tujuan dari penelitian ini diadakan ialah mengetahui pengaruh } \\
\text { likuiditasi, levegare, intensitas persediaan terhadap tingkat } \\
\text { agresivitas pajak pada perusahaan sub sektor manufaktur sub sektor } \\
\text { logam dan sejenisnya yang terdaftar di BEI tahun 2018-2019. } \\
\text { Penelitian ini menggunakan analisis descriptive dengan } \\
\text { menggunakan aplikasi SPSS25. Data sekunder yang digunakan } \\
\text { untuk penelitian ini diambil dari laporan keuangan } 15 \text { perusahaan } \\
\text { sub sektor logam tahun 2018-2019. Hasil penelitian menunjukkan } \\
\text { likuiditas dan agresivits pajak berpengaruh positif, leverage dan } \\
\text { agresivitas pajak berpengaruh negative dan intensitas persediaan } \\
\text { tidak berpengaruh terhadap agresivitas pajak. Secara simultan } \\
\text { likuiditas, leverage, dan intensitas persediaan tidak berpengaruh } \\
\text { pada agresivitas pajak. }\end{array}$ \\
\hline
\end{tabular}

\section{Pendahuluan}

Salah satu pendapatan terbesar oleh suatu negara didapatkan melalui pemungutan pajak baik individu maupun badan. Pajak dianggap sebagai hal dssar yang sangat mempengaruhi kelangsungan suatu negara. Adapun pengertiaan pajak menurut Andriani dalam (Ratnawati \& Hernawati, 2015) adalah suatu pungutan atau iuran dari masyarakat atau badan yang bersifat dipaksa dan pemungutannya didasarkan oleh undang-undang dimana biayanya akan digunakan untuk pengeluaran negara untuk menjalankan pembiayaan rumah tangga. Menurut (Adismartha \& Noviari, 2015) pembayaran-pembayaran yang digunakan untuk kepetingan masyarakat disebut juga pembiyaan rumah tangga Negara.

Walaupun pajak bersifat wajib dan memaksa, namun tentu banyak dari wajib pajak berusaha untuk menghindari pajak, terutama untuk perusahaan karena dianggap sebagai beban yang tidak menguntungkan perusahaan dan mengurangi laba perusahaan. Perusahaan dapat memanipulasi laporan keuangan demi menghindari pembayaran pajak atau yang disebut juga agresivitas pajak. Menurut Suyanto dalam (Wijaya \& Tiaras, 2015) agresivitas pajak merupakan usaha perusahaan dalam menghindari pembayaran wajibnya kepada negara baik secara sah maupun tidak sah sesuai pada ketentuan yang berlaku. Perusahaan yang merekayasa laporan keuangan berarti tidak menghilangkan tujuan utama dari laporan keuangan yaitu untuk mengambil keputusan sebaliknya apabila perusahaan memanipulasi 
laporan keuangan maka perusahan sedang melakukan hal illegal karna menghilangkan kegunaan laporan keuangan sebagai pertimbangan mengambil keputusan oleh investor.

Pada tahun 2018 ketercapaian penerimaan PPh pasal 21 sampai pada angka Rp 134,91 T $(14,56 \%)$ dibandingkan dengan pencapaian tahun lalu. Begitu juga dengan jumlah pekerja informal yang menurun $0.19 \%$ jika dibandingkan dengan jumlah tahun lalu. (Kementerian Keuangan Republik Indonesia).

Saat ini sudah cukup banyak penelitian untuk mengetahui faktor-faktor yang memberikan dampak pada kenaikan ataupun penurunan pada agresivitas pajak, salah satunya faktor likuiditas perusahaan. Menurut (Adismartha \& Noviari, 2015) Faktor likuiditas berpengaruh positif dan signifikan pada tingkat agresivitas pajak, berbeda dengan penelitian yg disampaikan oleh (Adiyani, 2017) ditemukan bahwa Likuiditas dan agresivias pajak tidak memiliki pengaruh signifikan.

Kondisi keuangan lainnya yang di prediksikan akan berpengaruh terhadap agresivitas pajak yaitu leverage. rasio yang memperlihatkan persentase pendanaan dari pihak luar yang dipergunakan oleh emiten sebagai biaya operasional perusahaan disebut juga leverage. Leverage juga dapat diartikan sebagai besarnya utang yang dimiliki oleh perusahan, dimana utang dapat mengurangi laba perusahan yang berdampak pada berkurang pajak yang akan di bayarkan perusahaan pada Negara. (Fikriyah, 2013) menyatakan leverage dan agresivitas pajak tidak memiliki pengaruh yang signifikan, hasil yang sama juga ditemukan oleh (Adismartha \& Noviari, 2015), sedangkan (Purwanto, 2014) dan (Dharma \& Ardiana, 2016) menyatakan bahwa leverage dan agresivitas pajak memiliki pengaruh signifikan.

Tingginya Inventory intensity tentu mempengaruhi beban pengeluaran emiten yang semakin tinggi, biaya ini meliputi biaya beban, biaya produksi, biaya tenaga kerja, biaya administrasi, boiaya penjualan, serta biaya-biaya lainnya yang dapat diakui untuk mengecilkan pembayaran pajak oleh perusahaan. Menurut (Adismartha \& Noviari, 2015) inventory intensity memberikan pengaruh positif pada agresivitas pajak, bertentangan dengan (Diana, 2013) yang berpendapat bahwa antara inventory intensity dan agresivitas pajak tidak memiliki pengaruh.

\section{Kajian Teori dan Telaah Literatur}

\section{Likuiditas}

Menurut Kieso, Weygandt, dan Warfield (2018), kesanggupan substansi untuk membayar short - term liability (debt) dalam waktu yang yang sudah ditetapkan dan (Suyanto dan Supramono,2012) memberikan penjelasan utang jangka pendek dapat berpengaruh terhadap kewajiban pajak tersebut. Jika perusahaan memberikan laporan cash flow yang baik akan berdampak terhadap likuiditas yang di miliki oleh perusahaan menjadi tinggi sehingga tidak ada masalah bagi perusahaan tersebut untuk membayar pajak sesuai peraturan yang berlaku.

Sebuah perusahaan mempunyai rasio likuiditas yang tinggi apabila total asset lebih tinggi dari hutang jangka pendek yang harus dibayar . Karna itu, jika likuiditas pada suatu emiten besar maka besarnya pajak yang akan dibayarkan oleh perusahaan menjadi sesuai kondisi keuangan perusahaan. Dan perusahaan juga tidak akan taat terhadap pajak jika likuiditas rendah untuk mempertahankan arus kas perusahaan. Likuditas dapat dirumuskan sebagai berikut:

$$
\text { Ratio lancar }=\frac{\text { asset lancar }}{\text { kewajiban lancar }}
$$




\section{Leverage}

Leverage menurut (Keown, et.al,2005) mengungkapkan penggunaan aktiva ataupun dana Hutang yang mempunyai biaya bunga yang tetap tentu dapat menjadi beban tetap bagi perushaaan, namun dengan adanya hutang jangka panjang ini diharapkan dapat menjadi suntikan dana untuk mengembangkan produksi perusahaan sehingga medapat keuntungan yang jauh lebih besar dari sebelumnya bahkan dapat membayar beban bunga untuk setiap bulannya. Dalam memenuhi sumber dananya perusahaan kemungkinan menggunakan utang. Dari utang perusahaan tersebut akan menimbulkan interest yang dibebankan kreditur kepada perusahaan. Leverage dapat dirumuskan sebagai berikut:

$$
\text { Leverage }=\frac{\text { total kewajiban }}{\text { total aktiva }}
$$

\section{Intensitas persediaan}

Persediaan ialah rasio yang membandingkan besarnya persediaan dalam satu perusahaan pada total aktiva. PSAK No. 14 (revisi 2008) dalam Anindyka, et al. (2018) menyatakan biaya tambahan yang tampak karena kapitalisasi produksi inventory haus diakui sebagai biaya dalam proses produksi dan dipisahkan dari biaya inventory itu sendiri. Berikut adalah rumus inventory intensity:

$$
\text { Intensitas Persediaan }=\frac{\text { Jumlah barang dalam gudang }}{\text { jumlah aktiva }}
$$

\section{Agresivitas pajak}

Kewajiban pajak perusahaan ialah Tindakan yang seharusnya perusahaan lakukan secara khusus, untuk mendapatkan negoisasi dengan tujuannya memperkecil biaya terhadap pajak. Tetapi perseroan yang bersifat terlalu memaksakan untuk memperkecil biaya pajak akan tidak terbuka pada laporan keuangan yang disajikan. Saat akan melakukan agresivitas pajak tentu semua badan harus mematuhi aturan-aturan perundang-undangan yang berlaku agar tidak merugikan Negara secara berkala dan berkesinambungan, karena pajak digunakan untuk mendanai fasilitas public seperti sekolah, rumah sakit, jalan raya, dan lainnya menurut Yoehana dalam (Adiyani dan Septanta, 2017). Kewajiban pajak dalam perusahan dapat kita hitung dengan:

$$
\mathrm{ETR}=\frac{\text { income tax expense }}{\text { earning before } \mathrm{TAX}}
$$

\section{Pengaruh Likuiditas Terhadap Agresivitas Pajak}

Sebuah perusahaan mempunyai rasio likuidits yang tinggi jika jumlah current asset > current liabilities. Jika ratio likuiditas nya tinggi besar kemungkinan pajak yang dibayarkan oleh emiten juga tinggi, dan perusahan juga kemungkinan besar tidak akan taat terhadap pajak jika likuiditas rendah untuk mempertahankan arus kas perusahaan. (Yuliana \& Wahyudi, 2018) menyatakan bahwa likuiditas dan agresivitas pajak berpengaruh signifikan, sedangkan (Putri, 2014) berpendapat lain yaitu likuiditas dan agresivitas pajak tidak berpengaruh signifikan.Oleh sebab itu penulis menarik hipotesis sebagai berikut:

$\mathbf{H}_{1}$ : Likuiditas berpengaruh terhadap agresivitas pajak 


\section{Pengaruh Leverage Terhadap Agresivitas Pajak}

Perusahaan dalam mengelola usahanya sering kali menggunakan utang untuk tambahan modal dalam menjalankan operasional perushaaan, bunga dan biaya operasi harus dibayar tanpa memperdulikan tingkat laba perusahaan. Hal ini yang bisa membuat perusahaan melakukan penghindaran pajak dengan kebijaksanaan dapat meningkatkan pendapatan atau laba yang diterima (Andreas, 2009). (Yuliana \& Wahyudi, 2018) menyatakan adanya pengaruh leverage dan agresivitas pajak, (Tiaras \& Wijaya, 2015) memberikan pernyataan tidak adanya pengaruh leverage pada agresivitas pajak.Bedasarkan uraian diatas maka penulis merumuskan hipotesis:

$\mathbf{H}_{2}$ : Leverage berpengaruh terhadap agresivitas pajak

\section{Pengaruh Intensitas Persediaan Terhadap Agresivitas Pajak}

Biaya tambahan yang dikeluarkan diakui menjadi beban pada saat terjadinya biaya oleh karena itu akan berdampak pada turunnya pendapatan oleh perusahaan menurut Dharmadi dan zulaikha dalam (Anindyka, et al. 2018). Hal ini juga dapat menjadikan perusahaan untuk melakukan agresivitas pajak. (Romadhina, 2019) menyatakan hal sebaliknya inventory intensity tidak memiliki hubungan yang signifikan pada agresivitas pajak. Penulis merumuskan hipotesis:

$\mathbf{H}_{3}$ : Intensitas persediaan berpengaruh terhadap agresivitas pajak

\section{Metode Penelitian}

Penelitian ini menggunakan analisis deskriptif. Populasi dalam penelitian ini ialah perusahaan Manufaktur yang terdaftar di BEI subsektor logam dan sejenisnya tahun 20182019 sedangkan sampel pada penelitian sebayak 15 perusahaan. Likuiditas, Leverage,dan Intentisitas Persediaan adalah variabel bebas dalam penelitian ini dan Tingkat Agresivitas Pajak menjadi variabel terikatnya. Penelitian ini

menggunakan analisis statistic data yaitu uji asumsi klasik, descriptive statistic,koefisien determinasi, siginifikan test, regresi analisis. Persamaan regresi pada penelitian ini

$\mathrm{ETR}=\mathrm{B}_{0}+\mathrm{B}_{1}$ Likuidity $+\mathrm{B}_{2} \mathrm{DAR}+\mathrm{B}_{3}$ Inventory Intensity

Deskripsi :

ETR $=$ Agresivitas pajak

$\mathrm{B} 0=$ Konstans

B1,B2 = Coefficient

Liquidity $=$ Liquiditas

DAR $=$ Leverage

Inventory Intensity $=$ Intensitas Persediaan

\section{Hasil dan Pembahasan}

\section{Uji Asumsi Klasik}

Uji ini menggunakan P-P Plot Analisis untuk menentukan normalitas data, dengan hasil sebagai berikut: 


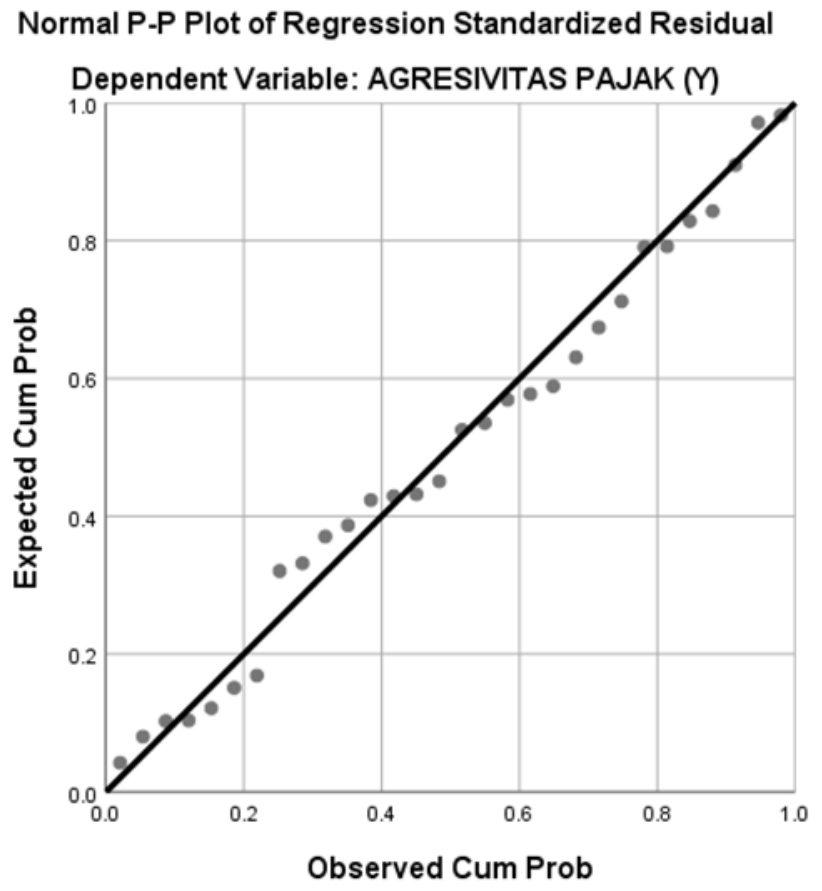

Gambar 1. Uji Normalitas

Grafik normalitas diatas menampilkan titik-titik diatas menyebar disekitar garis diagonal dan mengikuti arah garis tersebut, hal ini menyatakan data layak di gunakan karena memenuhi standar dalam uji normalitas data.

\section{Statistik Deskriptif}

Hasil perhitungan yang menggunakan bantuan spss menunjukkan hasil statistic descriptive pada penelitian ini terkait karakteristik variable dalam penelitian. Variabel Likuiditas menunjukkan seberapa mampu perusahaan membayar kewajiban lancarnya dengan menggunakan asset lancar yang ada pada perusahaan tersebut. Nilai Likuiditas dalam penelitian ini bernilai min 0,614 dengan nilai max 5,7882. Menunjukkan average yang kurang memadai yaitu $177 \%$ dibawah standar pemerintah yaitu $200 \%$.

Leverage ialah perbandingan untuk melihat berapa persentase asset emiten didanai oleh hutang. Adapun nilai min 0,1574 dan nilai max 3.7445. Menunjukkan hasil yang terlalu berisiko karena mean menunjukkan hasil $79 \%$ asset perusahaan didanai oleh hutang perusahaan sedangkan standar yang di tentukan untuk sektor industry sebesar 35\%.

Intensitas persediaan menunjukkan seberapa besar persediaan dalam perbandingan dengan jumlah asset, semakin efektif dan efisien sebuah perusahaan makan intensitas persediaannya semakin tinggi. Nilai min sebesar 0,326 dengan nilai max0,4969 dan mean sebesar 0,2346.

Agresivitas Pajak merupakan kegiataan perusahaan dalam menurunkan pajak yang harus dibayarkan. Nilai min -0,3058 dengan nilai max 0,8393 dan mean 0,1541, dan standar deviasi sebesar 0,2771. 


\section{Koefisien Determinasi}

Hasil SPSS menunjukkan bahwa didapati nilai $\mathrm{R}^{2}=0,072$, menunjukkan bahwa likuiditas, intensitas persediaan, leverage hanya mempengaruhi agresivitas pajak sebesar $7,2 \%$ dan selebihnya oleh faktor lain.

\section{Hasil Pengujian Hipotesis}

Hasil SPPS signifikan test menyatakan likuiditas, leverage, dan intensitas persediaan secara simultan apabila dilihat dari nilai F - Test sebesar 1,754 dan didapati nilai signifikan 0,181 pada $\alpha=0.05$. Hasil menyatakan likuiditas, leverage dan juga intensitas persediaan dan agresivitas pajak tidak berpengaruh secara simultan.

Nilai koefisien regresi variabel Likuiditas yang diukur dengan current ratio sebesar 0,049. Hasil ini menunjukkan hubungan likuiditas dan agresivitas pajak berpengaruh positif. Mengindikasikan setiap kenaikan 1 likuidtas berarti menaikkan ETR sebesar 0,049

Nilai koefisien Leverage yang diukur dengan DAR sebesar -0.012. Hasil menyatakan leverage dan agresivitas pajak berpengaruh negative. Mengindikasikan setiap kenaikan 1 leverage akan mengurangi agresivitas pajak yang di ukur dengan ETR sebesar 0,012.

Nilai koefisien Intensitas Persediaan yang di ukur dengan membandingkan jumlah persediaan dengan total aktiva sebesar 0,753 . Hal ini menunjukkan hubungan antara Intensitas Persediaan dan agresivitas pajak tidak berpengaruh signifikan.

\section{Pembahasan}

\section{Pengaruh Likuiditas Terhadap Agresivitas Pajak}

Antara likuiditas dan agresivitas pajak berhubungan signifikan positif sebesar 0,049 dibawah standar 0,05 . Ini berarti hipotesa 1 diterima. (Adismartha \& Noviari, 2015) dan didukung oleh (Yuliana \& Wahyudi, 2018) juga menyatakan bahwa likuiditas mempengaruhi agresivitas pajak secara signifikan.

\section{Pengaruh Leverage Terhadap Agresivitas Pajak}

Terdapat hubungan yang signifikan negative antara leverage dan likuidtas dilihat dari nilai signifikansi sebesar -0,012 dibawah 5\% . Hal ini menunjukkan H2 diterima. (Suyanto \& Supramano, 2012) berpendapat leverage dan agresivitas pajak berpengaruh signifikan dan hasiil yang sama dinyatakan juga oleh (Nugraha, 2015).

\section{Pengaruh Intensitas Persediaan Terhadap Agresivitas Pajak}

Antara intensitas persediaan dan agresivitas pajak tidak berpengaruh signifikan dilihat dari nilai signifikansinya $>0,05$ yaitu 0,753. Hal ini menunjukkan H3 ditolak. Penelitian ini juga di dukung oleh (Adismartha \& Noviari, 2015) dan (Wulansari, Titisari, \& Siti, 2020).

\section{Simpulan}

Berdasarkan penelitian yang di lakukan pada perusahaan sub sektor Manufaktur logam dan sejenisnya pada tahun 2018-2019 sesuai penjelasan yang sudah diuraikan diatas, kemudian diperoleh kesimpulan bahwa likuiditas berpengaruh signifikan positif dan leverage berpengaruh secara signifikan negatif terhadap Agresivitas Pajak, sedangkan intensitas 
persediaan tidak berpengaruh secara signifikan terhadap agresivitas pajak. Sehingga dapat disimpulkan likuiditas dan leverage akan mempengaruhi agresivitas pajak suatu perusahaan sedangkan intensitas persediaan tidak berpengaruh.

Saran untuk penelitian selanjutnya adalah dengan mencari lebih banyak variabel yang dapat mempengaruhi agresivitas pajak dan memilih pendekatan uji beda yang dapat mengkonfirmasi hasil penelitian dengan sewajarnya.

\section{Referensi}

Adismartha, I. B., \& Noviari, N. (2015). Pengaruh Likuiditas, Leverage, Intensitas Persediaan Dan Intensitas Aset Tetap Pada Tingkat Agresivitas Wajib pajak Badan. E-Journal Akuntansi Universitas Udayana, 13, 973-1000.

Adiyani, N. d. (2017). Pengaruh Likuiditas dan Profitabltias dengan CSR sebagai Variabel Intervening ( Studi Empiris Pada Perusahaan Property dan Real Estate yang Terdaftar di Bursa Efek Indonesia Tahun 2010-2014. Jurnal Ilmiah Akuntansi Universitas Pamulang, 5 .

Dharma, M. S., \& Ardiana, P. (2016). Pengaruh leverage, intensitas aset tetap, ukuran perusahaan, dan koneksi politik terhadap tax avoidance. E-Jurnal Akuntansi Universitas Udayana.

Diana, L. (2013). Pengaruh corporate governance dan intensitas persediaan terhadap manajemen pajak (Studi Empiris Pada Perusahaan Manufaktur Yang Terdaftar di Bursa Efek Indonesia Tahun 2011-2013) . Faculty of Economic Riau University, Pekanbaru, Indonesia .

Fikriyah. (2013). analisis pengaruh likuiditas, leverage. profitabilitas dan karakter kepemilikan terhadap agresivitas ajak perusahaan. . jurusan manajemen fakultas ekonomi UIN MALIKI Malang. .

Kementerian Keuangan Republik Indonesia. (n.d.). Direktorat jenderal Pajak. Retrieved November 22, 2020, from https://www.pajak.go.id/id: https://www.pajak.go.id/sites/default/files/2019-

11/Laporan\%20Tahunan\%20DJP\%202018\%20-\%20bahasa \%20Indonesia.pdf

Nugraha, N. B. (2015). PENGARUH CORPORATE SOCIAL RESPONSIBILITY, UKURAN PERUSAHAAN, PROFITABILITAS, LEVERAGE DAN CAPITAL INTENSITY TERHADAP AGRESIVITAS PAJAK (Studi Empiris pada Perusahaan Non-Keuangan yang Terdaftar di BEI Selama Periode 2012-2013). Fakultas Ekonomi dan Bisnis Undip, 183.

Purwanto, A. (2014). Pengaruh likuiditas, leverage, manajemen laba, dan kopensasi rugi fiskal terhadap agresivitas pajak perusahaan pada perusahaan pertanian dan pertambangan yang terdaftar di bursa efek indonesia periode 2011-2013. . departement of Accounting, Faculty of Economics Universitas Riau.

Putri, Y. (2014). Pengaruh Likuiditas, Manajemen Laba Dan Corporate Governance Terhadap Agresivitas Pajak Perusahaan (Studi Empiris Pada Perusahaan Yang Terdaftar Di BEI Periode 2008-2012). Jurnal Akuntansi, 2, 1-25.

Ratnawati, J., \& Hernawati, R. I. (2015). Dasar-Dasar Perpajakan. Yogyakarta: CV Budi Utama. 
Romadhina, A. P. (2019). Pengaruh Beban IKlan Dan Intensitas Persediaan Terhadap Agresivitas Pajak. Journal of Economic and Management Scienties, 2, 1-13.

Suyanto, K. D., \& Supramano. (2012). Likuiditas, Leverage, Komisaris Independen, dan Manajemen laba Terhadap Agresivitas Pajak Perusahaan. Jurnal keunagan dan Perbankan, $16,167-177$.

Tiaras, I., \& Wijaya, H. (2015). Pengaruh Likuiditas, Leverage, manajemen Laba, Komisaris Independen, dan Ukuran perusahaan Terhadap Agresivitas Pajak. Jurnal Akuntansi Universitas Tarumanagara, XIX, 380-397.

Wijaya, H., \& Tiaras, I. (2015). Pengaruh Likuidasi, Leverage, Manajemen Laba, Komisaris Independen, dan Ukuran Perusahaan Terhadap Agresivitas Pajak. Jurnal akuntansi e-JA, 19.

Wulansari, T. A., Titisari, K. H., \& Siti, N. (2020). Pengaruh Lverage, Intensitas Persediaan, Aset Tetap, Ukuran Perusahaan, Komisaris Independen Terhadap Agresivitas Pajak. Jurnal Akuntansi \& Ekonomi FEB.UN PGRI Kediri, 5, 69-76.

Yuliana, I. F., \& Wahyudi, D. (2018). Likuiditas, Profitabilitas, Leverage, ukuran perusahaan, Capital Intenity Dan Inventory Intensity Terhadap Agresivitas Pajak. Dinamika Akuntansi, Keuangan dan Perbankan, 7, 105-120. 